This is an Accepted Manuscript of an article published by Taylor \& Francis in Journal of Teaching in Travel \& Tourism on 16 May 2013, available online:

http://www.tandfonline.com/doi/abs/10.1080/15313220.2013.786312

\title{
Academic Agency and Leadership in Tourism Higher Education
}

\author{
Dianne Dredge \\ School of Tourism and Hospitality Management \\ Southern Cross University, Gold Coast, Australia \\ Dianne.Dredge@scu.edu.au
}

\section{Christian Schott}

School of Management

Victoria University of Wellington

New Zealand

Christian.Schott@vuw.ac.nz

\begin{abstract}
This paper explores the leadership agency of tourism faculty in higher education and recommends actions to enhance leadership for social change. Based on a review of literature grounded within an agency perspective, a conceptual framework is presented that identifies systemic and individual influences on leadership. Three types of freedom for faculty to engage in leadership behaviors arise: (1) the capacity of the individual to lead; (2) the freedom afforded by the organizational context to lead in accordance with one's capacity to lead; and (3) the social freedom to lead derived from each faculty member's disciplinary and departmental norms and structures.
\end{abstract}

Keywords: academic agency, leadership, tourism studies, higher education, social action.

Running Head: Academic Agency and Leadership in Tourism Education 


\section{INTRODUCTION}

Leadership in higher education has received increasing attention at both theoretical and practical levels over the last 20 years (Kezar \& Carducci, 2006; Marshall, Orrell, Cameron, Bosanquet, \& Thomas, 2011; Ramsden, 2003). This interest is driven in part by the push for higher education institutions in both developed and emerging economies to adopt business management and corporate governance practices, as well as by increasing pressure to improve transparency and accountability in meeting a broad range of teaching, learning, research and engagement objectives (Marginson \& Considine, 2000). For example, higher education institutions in developed economies are expected to deliver on a range of national economic objectives to help fill employment gaps, promote innovation and improve competitiveness (Pusser, Kempner, Marginson, \& Ordorika, 2012). In emerging economies, improved access to and participation in higher education is seen as a key to improving living standards through increased employment and higher incomes. Despite these diverse expectations placed on universities in both developed and emerging economies, the wide adoption of new public management practices has generally resulted in a flattening of organizational structures, larger faculties and fewer hierarchical leadership roles (e.g. heads of school, deans, etc.). Instead, leadership roles have been distributed in a proliferation of nonhierarchical leadership positions including, for example, program directors, first year advisors, directors of teaching and learning, directors of research and so on. As a result, it has become increasingly apparent that universities across the world have dispersed leadership beyond the traditional hierarchical management structures (Acker, 2012; Drew, 2010; Inman, 2011; Seeber, 2011).

The aim of the paper is to explore the leadership agency of academic faculty in tourism higher education and to recommend actions that enhance leadership for social change. The concept of agency — or the effective capacity of an individual faculty member to make 
choices about when, where, why and how to lead - is key to understanding leadership. The paper seeks to explicitly build awareness of the leadership agency of tourism academics in their teaching, research and service roles through a synthesis of the literature and subsequent development of a conceptual framework. To date there has been very little attention to the potential leadership roles that tourism academics can play in the rapidly changing context of higher education (Pearce, 2005b). There are, however, related discussions about hopeful tourism and several reflexive accounts of tourism academic's career development that contour around the edges of leadership (e.g. Ateljevic, Pritchard \& Morgan 2007; Nash, 2007; Gill, 2012). We choose to focus less on these personal characteristics, traits and behaviors of tourism academics who lead (e.g. see Nash (2007) in the anthropology of tourism, Smith (2010) in tourism geography and Pearce (2011) in tourism psychology), but instead we focus more on how human agency is socially constructed within the higher education environment. We argue that these reflexive personal explanations of career development provide little theoretical understanding about how cultural, social and institutional systems in higher education shape leadership. As an alternative, we ground our work within an agency perspective, arguing that the calculative action of tourism (and indeed all) academic faculty to lead is socially constructed through the interplay of the personal values, behaviors and qualities of individuals, and the range of social, organizational, political, economic and other factors. We argue that understanding the leadership agency of tourism academic faculty in their teaching, research and service activities is an important first step in pursuing social change through tourism.

In addressing the above aim, this paper will first explore the key concepts of leadership and academic agency. Following this, a range of systemic influences, which operate at multiple scales to influence the freedom of faculty to lead, will then be discussed. The paper will then 
engage with the values and aspirations of the tourism academy with respect to worldmaking, a discourse that is shaping the way leadership is socially constructed and collectively framed. Finally, we undertake a discussion of academic freedom to better understand the influences upon individuals, academic collectives and higher education institutions in terms of how leadership is enhanced and constrained. Drawing from these threads, a conceptual framework is presented that outlines the influences on leadership.

\section{LEADERSHIP AND ACADEMIC AGENCY}

\section{Leadership}

While definitions of leadership abound (e.g. see Jackson \& Parry, 2008, Northouse, 2009), for the purposes of this paper, leadership is broadly conceptualized as the mobilizing of human, intellectual and social capital and resources to achieve some desired future state. Three dimensions are inherent in this conceptualization of leadership: the exercise of leadership requires both leaders and followers; the capacity to mobilize requires communication and interpersonal skills; and to lead requires actions towards goals (Jackson \& Parry, 2008). Jackson and Parry (2008) argue that simple transactions such as undertaking tasks to fulfill a contract or obligation, are a form of management or "transactional leadership" (see Bass, 2008). Transactional leadership is distinguished from transformational leadership because the latter involves multiple decisions and trade-offs between alternative consequences where there is usually no clear solution or path to follow. The leader needs to influence and inspire those around her/him (i.e. followers) into individual and collective action, the sum of which is more than if individuals acted alone. This notion of transformational leadership has been described as a form of leadership that inspires action, ignites passion in followers and leads to transformation (Bass, 2008). 
In the business studies literature, where leadership has been a theme of research for some decades, a highly developed body of theory has evolved which predominantly focuses on the behaviors of individual leaders (Bass, 2008). In this literature, leadership is synonymous with improved profitability, competitiveness, market position, brand awareness and other such goals. In organizational psychology, there is also a rich body of research that interrogates the personal characteristics and humanistic qualities of leaders (Haslam, Reicher, \& Platow, 2011; Maslow, 1987; Messick \& Kramer, 2005). Leadership has also been widely examined within sociology, politics, public policy and organizational studies, with theoretical developments grouped into four main perspectives reflecting how leadership has historically been explained:

- Trait theories argue that leadership is derived from the personality traits and characteristics of leaders and generally hold that leaders are charismatic, born that way, and cannot be trained;

- Behavioural theories hold that leadership is exercised through patterns of behavior which can be learned (i.e. leaders are not just born that way);

- Contingency theories argue that effective leadership depends upon context and, thus, is distinguished from trait and behavioural theories that focus on the individual. Contingency theories focus on understanding specific situations and the influence of exogenous and endogenous influences;

- Integrative theories combine the above theories, but also attempt to acknowledge relationships between leaders and followers, with transformational and distributive leadership theories being the most well known of this group (see Bass \& Riggio, 2005; Rafferty \& Griffith, 2004). An integrative theory which has recently gained considerable momentum in the management literature is authentic leadership, which 
places a strong focus on awareness of the self, others and contexts (see Avolio \& Gardner, 2005; Walumbwa, Avolio, Gardner, Wernsing \& Peterson, 2008)

While much discussed in the broader higher education context (e.g. see Inman, 2011; Jones, Applebee, Harvey, \& Lefoe, 2010; Kezar \& Carducci, 2006; Richards, 2012), understandings of leadership have generally focused on formally designated roles such as heads of schools, deans, research chairs and other senior managers (Kezar, 2000; Macfarlane, 2011).

Leadership, however, has not been directly discussed in relation to tourism let alone tourism education. Despite this gap, there is a growing discourse around the need to frame tourism education in terms of producing graduates who are mindful of tourism's impacts and can manage tourism to improve the human condition (Hollinshead, 2009; Pritchard, Morgan, \& Ateljevic, 2011; Morgan 2012). Contemplating how to achieve social change through tourism, and who drives this, suggests that a discussion about leadership is overdue. Here, the agency of academic faculty becomes relevant and a number of questions emerge such as: How can individual academics lead and drive social change? What are the opportunities for collectives of tourism academics to demonstrate leadership? What are the impediments to exercising leadership?

\section{Agency and Action}

Theories of action have historically been discussed in philosophy in terms of the purpose, reasons and motivations for individual action, but made little impact in social sciences until the 1970s and 80s. This is because these discussions focused on the individual realm and did not pay much attention to the influence of broader socio-cultural and institutional conditions that influence social change (Giddens, 1979). By the 1980s, agency theory, which explores the freedom and capacity of agents to act within the social context, began to receive 
increasing attention. In sociology for example, Giddens' (1984) proposed a structure-agency theory wherein agency and structure were theorized in a dialectical relationship. Agency was defined not as the sum of discrete acts, but as flow of conduct. The capacity of individuals to independently develop this flow of conduct was shaped by structures (i.e. rules, routines and other patterned arrangements) that shape the choices available to them to act. Further, agency resides not only in individuals, but also in institutions and things. Sen $(1985,1999)$ outlined a theory of capability development, which explored how different dimensions of freedom shape human capability; and in psychology there are theories of control, self-regulation and self-efficacy (e.g. Crockett, 2002). Further, in business and economics, the principal-agent approach has explored the nature of the transactional relationship between principals (who delegate work) and agents (who perform the work on the principal's behalf). This transactional relationship is metaphorically known as a contract (Eisenhardt, 1989), and how a contract is enacted is influenced by a range of factors including alignment of goals, obligation, reciprocity, risk and self-interest between principal and agent (Jensen \& Meckling, 1976; Ross, 1973).

These streams of research have delivered understandings about how individual and collective perceptions of the capacity to act are shaped by an interlocking network of social, cultural, economic and political forces. However, application of this agency perspective in higher education has received limited attention, and is made more difficult because principal and agency roles are unclear (Marginson, 2008). For example, governments (principals) require universities (agents) to deliver on national education policy objectives. At the same time universities (principals) require individual academic staff (agents) to deliver on a range of teaching and research objectives. Further, fee-paying students (principals) expect their teachers (agents) to meet high quality teaching standards and deliver course objectives. All 
have agency, make choices and undertake purposive action based on (1) perceptions of their own resources, levels of control and capacity to act or lead; and (2) evaluations of the benefits and consequences of alternative actions. Despite these difficulties in conceptualizing agency, it is useful in considering leadership in higher education because it reminds us that leadership exists in a variety of relationships and in multiple actors and does not exist outside the social context. That is, agency (in our case, the capacity to lead) does not just reside in those formally appointed to leadership roles but can be distributed in individuals, universities, government and in the market place.

However, conceptualizing leadership and understanding the agency of academics, either as individuals or as a collective, are two very different things. Leadership can be a person, a result, a position or a process, which makes it difficult to identify, explain and understand leadership in action (Jackson \& Parry, 2008). Grint (2005) argues that we have become far too focused on leaders and their individual qualities and that focusing on leadership in a more holistic sense, which takes into account social cultural and institutional influences, is also needed. He argues that the social construction of the context (e.g. in many developed economies higher education is characterized as a regulated neoliberal market-driven system) legitimates particular types of actions, constitutes the world and the leadership challenge in the process. For example, the neoliberal agenda dictates an emphasis on competition, cost effectiveness and mass market efficiencies, so leadership that delivers on this agenda will be deemed 'good leadership'. However, different renderings of the context (e.g. an emphasis on effective learning, access to socio-economically disadvantaged groups or employability) will produce different leadership orientations and opportunities for academic agency. 
For Jackson and Parry (2008), constructing the leadership context is complex; there are multiple competing agendas, problems and solutions. The challenge of leadership is to appreciate the complexity of the problem space and to take action, sometimes without a clear understanding of where such actions will lead. The rapidly globalizing higher education sector discussed below, with its attendant pressures on teaching, research and service, exemplifies the complex system of social forces at play.

\section{SYSTEMIC INFUENCES ON HIGHER EDUCATION}

Across the world, higher education has been in a constant state of reform for five decades (Van Der Wende, 2007). After World War II many developing countries began to actively restructure their economies to position themselves in a rapidly globalizing and increasingly mobile world (Gamage \& Mininberg, 2003; Teichler, 2003; Tynan \& Mark, 2009). By the 1970s many of these countries started to deindustrialize and shift their economic emphasis from manufacturing to tertiary sectors, higher education policy became increasingly tied to national economic objectives such as developing the knowledge economy, meeting new labor force needs and promoting innovation and economic diversity. Pressures including globalization, increased competition, shifting student markets and consumer trends, the increasing imperative of sustainability, changing work patterns and characteristics of work and innovations in the Information and Communications Technology (ICT) arena have resulted in transcendental change in higher education (Marginson, 1999; Marginson \& Considine, 2000; Marginson \& Sawir, 2005). Further, new public management has contributed to a decrease in public funding in most higher education systems relative to private revenue streams; there is upward pressure on student fees to cover ballooning costs, and new public management practices have been adopted that focus predominantly on performance, productivity and profitability (Van Der Wende, 2007). 
While this paper focuses on developed countries, since 2000 the role of higher education in improving living standards and progressing economic development, competitiveness and globalization objectives in emerging economies has been increasingly emphasized (Van Der Wende, 2007). As a result, parallels can be drawn between the evolution of higher education systems in developed countries and the present paths of developing countries which are predicted to follow similar trajectories (Marginson \& Rhoades, 2002).

\section{Implications for organizations}

In many universities in developed economies, the result of all these intersecting pressures has been the decline in Socratic and craft-based teaching practices, the industrialization of teaching processes, practices and materials, and the development of highly diversified mass student markets (Marginson \& Considine, 2000; Trowler, 2010). Larger numbers of students can attend university in different study modes (i.e. internal, external and off-shore). Academic educators are under increasing pressure to deliver on a range of performance measures including teaching evaluations, research outputs, significance and measures of esteem (Phillips, 2005). Consistent with new public management approaches that seek to facilitate and enable the achievement of goals through partnerships and shared responsibility, university managers have become responsible for steering their institutions towards measurable outcomes (Coaldrake \& Stedman, 1999; Tynan \& Mark, 2009). One important consequence has been that leadership within many higher education institutions has become overly focused on "command and control" systems geared towards achieving corporate and commercial objectives (Sharrock, 2012). Less attention has been placed on the agency of academic faculty to lead in their teaching, research and service activities (Jones, Applebee, Harvey, \& Lefoe, 2010). 
Tourism programs find themselves in a vexed situation under these conditions. Tourism programs largely emerged out of a need to produce graduates to fill growing industry demands during the 1980s and 1990s (Pearce, 2005a). Located predominantly within business studies focusing on management with a social sciences flavor (Dredge et al., 2012; Tribe, 2002), and quite often heavily vocational in their curriculum orientation, tourism programs have struggled to gain academic credibility and contribute to measures of university reputation (i.e. rankings, significance) or to attract substantial external funding and sponsorship (Pearce, 2005b; Tribe, 1997). As a result, tourism has received little profile in many universities with managers responding by increasing support for publication outputs and the writing of grant applications in order to maximize their tourism faculty's contribution to corporate and commercial objectives or by merging tourism into larger faculties so they strengthen outcomes in other fields such as business. This emphasis on corporate objectives has anecdotally drawn academic faculty attention away from engagement with industry and community stakeholders, diverted efforts away from engagement with external communities towards 'ivory tower' pursuits in some cases, and inhibited interest in formal leadership positions (e.g. Head of School positions).

Given the extent and depth of these reform processes and the different stages through which developed and emerging economies are passing, it is important that universities not only deal effectively with the current pressures, but that they also position themselves as leaders into the future, anticipating and strategically positioning themselves to confront the challenges ahead (World Development Bank, 1999). Yet it is also true that universities have been around for hundreds of years, and while the modern university is quite different at both operational and structural levels, universities for the most part remain organized into disciplines with 
established cultures and academic practices (Tynan \& Mark, 2009, pp. 98-99). These disciplinary structures promote a certain level of stability within universities (Becher \& Trowler, 2001; Latour, 1987), thus opening up opportunities for academic collectives to provide leadership on important societal issues that transcends short-term political cycles associated with government elections.

\section{Implications for the Academy}

Professional Identity

There has been substantial discussion about the origins and development of tourism as a field of study (e.g. see Coles, Hall, \& Duval, 2006; Holden, 2005; Jafari, 1991, 2001, 2003; Tribe, 1997, 2006) with agreement that there are two broad but interrelated camps within tourism higher education research and teaching: the first is devoted to framing tourism as a business activity and teaching, where research and engagement activities are hinged on improving productivity, competitiveness and innovation; the second is characterized by a social science focus where teaching, research and engagement activities focus on the transformative qualities and effects of tourism on society (Tribe, 1997). Studies into academic identity and disciplinary location reveal that the level of socialization within 'disciplinary tribes' is significant in shaping how individual academics see and engage in the world (Becher \& Trowler, 2001). In Tribe's analysis of tourism he found that the field was characterized by a divergent community wherein a diversity of approaches is tolerated, however universities and departmentalism often force convergence and "tribal allegiances" to certain forms of knowledge and practice (Tribe, 2010). His findings also reiterated observations in the broader literature that suggest an academic faculty member's agency (i.e. their capacity to lead in this case) is inextricably tied to the effective agency that exists in the system in which they work (Calvert, Lewis, \& Spindler, 2011; Henkel, 2000, 2005; Whitchurch, 2012). 
Academic identity in tourism centers on a unique shared sense of purpose, practices and knowledge. The capacity of tourism to contribute to social change is increasingly acknowledged as a central interest with researchers arguing that academics need to embrace research and teaching practices that make a difference to societal issues and to produce graduates that can create a better world (Hollinshead, 2009; Hollinshead, Ateljevic, \& Ali, 2009; Pritchard et al., 2011; Ren, Pritchard, \& Morgan, 2010). In this vein, the Hopeful Tourism Academy is an alternative to the neoliberal, business orientated hegemony of tourism studies. The Hopeful Tourism Academy is based on practices of "cooperation, reciprocity, interdependence, activism and support" and seeks to emphasize responsibilities to each other and to global sustainability (Pritchard et al., 2011, p. 945). Tourism education, and by corollary, its institutions, academics and students, are placed squarely at the center of this challenge by virtue of the contribution higher education makes to the tourism industry's “talent pool”.

Yet there is a gap between what should be (i.e. social change) and how to get there (i.e. leadership by whom and how). Pritchard et al. (2011, p. 945) and Sheldon, Fesenmaier and Tribe (2011) argue that, to make a difference, academic faculty can pursue hopeful tourism by engaging in real problems, with real people and make a positive difference by addressing issues such as oppression, displacement, marginalization and social injustice. According to Higgins-Desbiolles and Whyte (2013) however, "people can hope for a world with greater justice while simultaneously failing to understand the need to confront the role their own privileges can play in reproducing injustice" (p.2). Hopefulness, they rightfully argue, "can be rife with insensitivity, ignorance and serious deficits in moral imagination" (p.2). Mindful 
attention and reflexive engagement is needed in what hopefulness is, and how it can be given meaning through teaching, research and community engagement practices.

Values

Building on a long history of interest in values-based education (Harland \& Pickering, 2011), the Tourism Education Futures Initiative (TEFI) has turned its attention to the importance of values in unlocking leadership in tourism higher education (see Table 1) (Sheldon et al, 2011). Values are abstract ideals, positive or negative, that shape both individual and the collective beliefs and attitudes about what is important (Sheldon et al., 2011). Ultimately, values guide leadership although they often remain implicit and their effects overlooked in the daily business of teaching, research and community service (Moscardo \& Murphy, 2011). TEFI has argued that a focus on values-based education provides an important foundation for tourism programs so that graduates develop the knowledge, skills and capacity to lead. It is also a collective response from educators to ensure that higher education meets its responsibilities to society, now and in the future.

Table 1 here

A number of educators have taken a leadership role, integrating these TEFI values within their teaching and incorporating them within program planning and curriculum design (e.g. Liburd, 2012; Gretzel, Isacsson, Matarrita, \& Wainio, 2011). Moscardo and Murphy (2011) have focused on developing a tool to measure values by embarking on the development of a TEFI Values Inventory. While this work is still in its early stages, it has nevertheless become clear that a great deal more work is required in interpreting and giving meaning to these values within the curriculum space, within students' learning experiences and environments, 
and how to measure these values in ways that are respectful to different cultural contexts and learning opportunities available to students. Accordingly, there is a need to better understand these values, and to better link them into a more cohesive and philosophical approach to leadership in tourism education.

The agency of academic faculty to lead in all facets of their academic work and the development of graduates with the skills and capacity to lead are closely aligned. HigginsDesbiolles (2010), Dredge and Hales (2010) and Lew (2012) argue for an engaged academic activist role in tourism research and service, a role that is deliberatively formed and mindful of the values embedded in research approaches, styles and tools of community engagement. Such academic activism provides important opportunities to link teaching and research and to demonstrate leadership. However, beyond this, "there is silence on the question of exactly how the academic's role in academia and research itself can serve as tools for communities to change their own conditions on their own terms" (Higgins-Desbiolles and Whyte, 2013, p.430). Addressing this question is made even more difficult by the rapid and sustained change in the higher education system and the way in which these changes shape academic work.

\section{Implications for Individual Faculty Members}

Academic Work Profiles

The changing nature of academic work has influenced the agency of academics in the following ways: First, the adoption of market models of higher education provision and performance-based measures in many countries have emphasized metrics, such as student satisfaction and graduate outcomes, which are increasingly used to classify universities for the purposes of funding and market comparison (Buchen, 2005, p. 17). As a result, 
consumers now wield more weight in terms of what programs are offered and how they are delivered. The impact on academic work has been both positive and negative: on one hand there is increasing pressure on academics to teach better, more creatively and engage their students, and on the other, rising student numbers and staff — student ratios have increased workload pressures (Davis, 2005; Trowler, 2010).

Second, performance measures have become marketing inputs for university marketing and branding. So important have these performance measures become that academic staff appraisals and professional development plans are increasingly shaped by these metrics (Bexley, James \& Arkoudis, 2011). The impact on academic work has been increased time spent on collecting, documenting and analyzing metrics. However, on a positive note, academics' self-reflexive processes along with institutional support can often result in improved performance and emergent forms of leadership as academics discover what they are good at.

Third, and related to the above two points, increased internationalization, liberalization, harmonization and competition have increased awareness of higher educational products and services (Coaldrake \& Stedman, 1999). Not only is there increased competition amongst institutions for enrolments, but the sector is characterized by increasing mobilities of the academic workforce, of academic institutions (onshore and off shore student cohorts, overseas campuses, partner institutions) and students (Bok, 2003). The impact on academic work can be viewed both positively and negatively: personal and professional growth and potentially, global leadership, can result from increased mobilities, however travel and developing cross-cultural work practices can be time consuming and detract from efforts to develop international leadership opportunities. 
Fourth, an emphasis on the consumer, increased mobilities of the student market, and diversity in student markets has simulated demand for more customized and personalized learning services and environments (Atkins, 2005; Hazelkorn, 2011). Larger classes and higher student-staff ratios have dictated the need for greater flexibility and creativity in the use of mobile technologies and byte-sized learning packages that students can engage with in their own time. In many institutions, responses have been to replace the traditional lecture format with more interactive and personalized learning activities. The implications for academic work include a need for staff to upskill in mobile technologies, changes to the way they prepare and implement lesson plans, and the development and maintenance of online learning materials (Kogan \& Teichler, 2007).

Fifth, the above changes have also led to increased openness and collaboration both for students in their learning and academic staff in their research with potential for collectives of academics to lead. Important trends that are shaping the way learning takes place include the democratization of learning opportunities (e.g. University of the People, www.uopeople.org); the global delivery of massive open online courses (e.g. Coursera, www.coursera.org, Udacity, www.udacity.com); and community driven collaborative learning (e.g. unclasses, www.unclasses.org). While the effects of these innovations on academic work and leadership are not yet clear, the longer-term implications of these offerings are expected to bring positive and negative transformation to higher education.

Sixth, the pressure for academics to produce high quality research with demonstrated significance and impact is significant (Atkins, 2005; Dale, 2000). Research excellence frameworks in many countries have placed considerable pressure on academics to become 
more effective and efficient in the way they produce research and to gather evidence of their esteem (e.g. leadership) (Smith, Ward, \& House, 2011). The impact on academic work has been in the transformation of research practices, particularly in the social sciences, from individualist craft-based approaches to more industrialized team-based approaches that require leaders. The impact of these changes can also be viewed in both positive and negative terms. For example, these shifts have resulted in many academics becoming more active and productive in their research endeavors by virtue of their engagement in larger teams of researchers where specialist skills can be pooled and greater learning opportunities can be leveraged. On the negative side, where academics have not been able to navigate this new playing field, the impact on some academics has been marginalization and reallocation of their research workload component to other researchers (Coles, 2009) and anecdotal evidence suggests that there are cases of academics deemed research 'inactive' receiving very strong encouragement to leave the institution. By virtue of these pressures, academic leaders have variously emerged in teaching, research and service activities.

These pressures on academic work, generated by a range of external and institutional conditions, have implications for the individual agency of academic faculty members to exercise leadership in their teaching, research and service commitments. In an attempt to make sense of academic work, and to better identify where leadership agency exists and has the potential to develop, it is useful to consider Boyer's four dimensions of academic scholarship. Boyer (1990) called for a repositioning of academic work to pursue four key dimensions of scholarship:

- The scholarship of discovery - traditional research that builds new knowledge

- The scholarship of integration - interprets and gives meaning to knowledge making connections across disciplines 
- The scholarship of application - application of knowledge to help solve societal problems

- The scholarship of teaching - intellectual engagement in the practice of teaching to educate and entice future scholars.

Following Nussbaum's $(1997,2010)$ arguments for the humanities and social sciences to address pressing social, civic, economic and moral problems, Boyer's dimensions of scholarship have been widely endorsed because they refocus academic work on society's 'big questions'. For example, how tourism can contribute to poverty alleviation, improve equity, tolerance, self-determination and quality of life are all "big" questions. Very real questions have been raised with respect to the agency of academic faculty members in addressing these 'big questions' given the neoliberal values embedded in university vision statements, values and management plans, (Pritchard et al., 2011; Pusser et al., 2012).

\section{ACADEMIC FREEDOM, INDIVIDUAL AGENCY AND WORK PROFILE}

The principle of academic freedom, originally articulated by W. von Humboldt in the establishment of the Berlin University in 1809 , remains a fundamental plank of the modern university and is intimately tied to the modern concept of academic agency. The original ideal of academic freedom envisioned freedom of research and teaching, integrated in such a way that students build an intellectual life — the highest form of moral life — and a commitment to humanity (McCarty, 2011). In the modern university, McInnis (2000) found that academics are highly socialized into their professional roles through their disciplinary experience and location, but they also tend to exercise a high degree of self-direction in terms of their teaching approaches and research activities (see also Adams, 1998; Calvert, Lewis, \& Spindler, 2011; Henkel, 2005). However, this academic freedom has resulted in a range of 
issues for university managers including, for example, difficulty in managing the academic workforce, a lack of quality control and large variations in degree standards. Neoliberal management practices introduced over the last 10 years have sought to address these issues and, in the process, limited some academic freedoms previously enjoyed.

In this neoliberal university, academic freedom is now tempered by the pressures of 'deliverables', employment contracts, union agreements, modern work practices, students' expectations for professional degrees and work readiness, all of which distract from the moral ideal of education for humanity. To illustrate, an interesting insight into the neoliberal reforms on New Zealand universities, which are declared as both 'critic and conscience of society' by the Education Amendment Act (1989), is offered by Harland, Tidswell, Everett, Hale and Pickering (2010). These authors conclude that the reforms "leave academics with less freedom to act as critic and conscience and may finally threaten the democratic role the university plays in society" (p.95).

As a result, earlier conceptions of academic freedom described above have been revisited by those interested in how the freedom to act is shaped by (1) the capacity of the individual to act (agency freedom) and; (2) the freedom afforded by the organizational context or setting (effective freedom) to act in accordance with one's own beliefs (Marginson \& Rhoades, 2002). To this, we also add (3) the notion of a social freedom derived from the disciplinary norms and structures within which an academic operates. With respect to agency freedom, leadership theories can highlight the behavioral characteristics, traits, and the relationships between leaders and followers which are necessary for an individual to exercise leadership. However, individual agency to lead is deeply entwined with social (e.g. academic tribes, 
departmentalism, etc.) and organizational (e.g. university) environments and the latitude that these arrangements afford individual faculty members to take action.

For example, studies of the academic workforce are replete with observations about the way new public management practices, neoliberalism and globalization have depleted the agency of academics. Studies of the academic workforce reveal an aging workforce across many developed countries (Magner, 1999; Koopman-Boyden \& Macdonald, 2003; Ackers \& Gill, 2005; Hugo \& Morris, 2010;), and a desire by completed PhDs and early career academics to leave the academy (Huisman, Weert, \& Bartelse, 2002; Ackers \& Gill, 2005; Bexley, Arkoudis \& James 2011). There is also a casualization of the workforce occurring (Coates, Dobson, Goedegebuure, \& Meek, 2010; McInnis, 2000). A large study of the United States Higher Education system for example revealed that 60 percent of today's 1,138,734 faculty members are in full- and part-time appointments outside the tenure system, while in 1975 this proportion was 42 percent (Gappa, Austin \& Trice, 2007; Schuster \& Finkelstein, 2006). In many other countries, academics are poorly paid and many need to hold down more than one job, or permanent posts are not available and academics need what are called "portfolio careers" (Bexley, James, \& Arkoudis, 2011; Coaldrake \& Stedman, 1999). These portfolio careers require an individual to develop portfolios of expertise directed at different opportunities inside and outside the university (e.g. academics might act as consultants in addition to their academic duties or might contribute to a family business) (Anderson, Johnson, \& Saha, 2002; Kogan \& Teichler, 2007; Lyons, 2010). These conditions both constrain and provide opportunities for academics to embrace leadership inside and outside the university.

\section{DISCUSSON}


The aim of the paper was to explore the factors that affect the leadership agency of tourism faculty and recommend actions to promote leadership. The paper was premised on the idea that academic agency, which is shaped by organizational, social and individual factors, is key to better understanding how leadership opportunities emerge. From this review, a conceptual framework has been developed (see Figure 1).

Figure 1 here

In the introduction to this paper we noted that individual traits and behaviors, identity and personal circumstances are important in shaping the agency of academic faculty (see Bass, 2008; Jackson \& Parry, 2008). These are noted in the top right of Figure 1. However, given the attention already devoted to these factors in the leadership literature, and in the reflexive accounts of tourism academics (e.g. see Pearce 2011, Nash 2007, Smith 2010), we chose not to explore these aspects but instead to focus on the systemic influences which we argue have not yet been sufficiently explored in the literature (indicated in the top left of Figure 1).

Figure 1 conceptualizes leadership as being filtered through layers of interdependent factors starting with these systemic and individual influences. The factors influence (1) the organizational setting; (2) the disciplinary/departmental setting (i.e. the academy) and, (3) the individual faculty member's goals, values and identity. Leadership agency is produced through a process of mindful and reflexive engagement with these three contexts to identify what leadership opportunities and impediments are at play. These insights are then translated into the individual's work profile. This work profile includes a range of activities that can be broadly categorized into the four dimensions of leadership, as proposed by Boyer (1990) and 
the Carnegie Foundation: scholarship of discovery, scholarship of integration, scholarship of application and scholarship of teaching.

In Figure 1, we have sketched out a framework that reflects these insights drawn from literature, but the question remains "How can tourism faculty lead positive social change?" To seed dialogue on this important question we propose an exploratory list of actions which illustrate opportunities and strategies for leadership in tourism. To align this basic catalogue of actions with the conceptual framework we revisit Boyer's four dimensions of scholarship to position each action in a meaningful context. However, as clearly evident in Table 2, the placement of actions necessitates numerous instances of overlap across dimensions. On one hand, this is a reminder of the multitude of functions, both realized and potential ones, that academic roles perform. At the same time it is in keeping with the concept of scholarship, which for most academics is an overarching approach that finds application in all domains of academic life, including, but importantly not limited to 'research'.

As highlighted above, by devising this exploratory list we seek to stimulate dialogue about leadership in tourism higher education rather than suggesting for it to be an authorative or exhaustive list. Further, while we are not explicit about this in the table, it is inherent to all actions that opportunities for both individual and collective leadership exist; with the synchronization of several academic's agency to achieve collective leadership presenting particular challenges but offering powerful outcomes.

Table 2 here 
While it is not possible to expand on each of the suggested actions due to space constraints, we wish to briefly synthesis key themes in Table 2 . In the context of discovery, challenging the common parameters of what neo-liberal universities deem appropriate or valuable topics and techniques of enquiry present opportunities for academic leadership. Equally, leadership and academic agency are called on to catalyze the transition of tourism-related knowledge generation from Mode 1 to Mode 2 knowledge production, which is socially distributed, application-oriented, trans-disciplinary, and subject to multiple accountabilities (Gibbons, Limoges, Nowotny, Schwartzman, Scott, \& Trow, 1994). Opportunities which we envisage in the scholarship of integration domain include the translation, integration and dissemination of tourism-related knowledge in the contexts and forums where it has relevance and meaning. This undoubtedly includes transmitting knowledge to our tourism students and desseminating it in academic publications which fall under the tourism theme. However, the relevance and meaning of tourism-related knowledge branches far beyond these spheres by crossing disciplinary, geographical and cultural boundaries, as well as to a heterogeneous cohort of individuals who are non-specialists of tourism knowledge but important stakeholders in the generation and use of such knowledge.

The application domain provides a large platform for academics to apply their knowledge and skills to support positive social change. Acadmics can lead social change by critically commenting and contributing to government policy and practice, industry projects and needs, advise NGOs and actively support their work for social change and a better world, as well as crucially through their roles as teachers, mentors and role models to undergraduate and postgraduate students. The ability of academics to act as powerful facilitators of meaningful and deep learning is also of great significance here, as is academic activism and the role of an agent of institutionally-focused change. Naturally, some of these opportunities and strategies 
are also highly relevant to the scholarship of teaching domain which is characteristised by critical (self) reflection, active engagement with the generation of knowledge, and continual learning about the field, our learners and other stakeholders in tourism education. The opportunities for leadership arise out of these facets of the scholarship of teaching.

\section{CONCLUSION}

In tourism, there is increasing discussion about the "worldmaking" role of tourism, within which academic faculty have an important role and a responsibility to students, to the global community and to industry, to unlock the potential of tourism to improve the human condition. The leadership of academic faculty in pursuing social change is constituted through their interactions with students at both undergraduate and postgraduate level, with their disciplinary communities and external communities, and within the reflexive and mindful engagement in their own institutional contexts. Accordingly, we argue that leadership in tourism higher education is distributed across the different roles that academics undertake within their work and in different members of staff depending upon their institutional responsibilities and personal characteristics.

This paper has sought to review and synthesize the literature and in the process has opened up several opportunities for further research and empirical study. In particular, we have drawn inspiration and broad license from theories of agency and leadership, which provide inspiration for future research. Additionally, this review and synthesis has provided a starting point for dialogue about strategies and opportunities to catalyze, and hopefully lead, transformation of tourism higher education using the power of collective action. Additionally, we sought to develop a foundation for more robust theoretical and empirical study of 
leadership in tourism, which is needed if we are to address the challenges outlined by advocates of hopeful tourism.

Finally, in terms of implications for management, it is important to understand how tourism academics produce different renderings of the higher education environment that open up perceptions of their own agency and the type of leadership actions opened or closed off by their rendering. We need to better understand how to enhance and facilitate the agency of individual academics to progress their role in social change in the reflexive and sensitive manner called for by Higgins-Desbiolles and Whyte (2013). This may require an active reconstruction of the current polemic in higher education that seeks to reproduce ideas about the ascendancy of neoliberal public management and the attendant loss of academic faculty power and authority. Instead, we need a more textured, fine-grained and situated understanding of agency within different higher education contexts.

\section{Acknowledgements}

We wish to thank Dr Paul McDonald and Dr Sarah Proctor-Thompson of the Victoria Business School for their valuable comments on previous versions of this paper.

\section{REFERENCES}

Acker, S. (2012). Chairing and caring: gendered dimensions of leadership in academe. Gender and Education, 24(4), 411-428.

Ackers, L., \& Gill, B. (2005). Attracting and retaining 'early career' researchers in English Higher Education Institutions. Innovation, 18(3), 277-299. 
Adams, D. (1998). Examining the fabric of academic life: An analysis of three decades of research on the perceptions of Australian academics about their roles. Higher Education, 36(4), 421-435.

Anderson, D., Johnson, R., \& Saha, L. (2002). Changes in academic work: Implications for universities of the changing age distribution and work roles of academic staff. Canberra: Commonwealth of Australia.

Ateljevic, I. Pritchard, A., \& Morgan, N. (2007). (Eds) The Critical Turn in Tourism Studies: Innovative Research Methodologies. Oxford: Elsevier.

Atkins, D. (2005). University Futures and New Technologies: Possibilities and Issues OECD/CERI. Retrieved 15 December 2012 from http://www.oecd.org/education/highereducationandadultlearning/36758866.pdf

Avolio, B. J., \& Gardner, W. L. (2005). Authentic leadership development: Getting to the root of positive forms of leadership. The Leadership Quarterly, 16(3), 315-338.

Barber, E. (2011). Case Study: Integrating TEFI (Tourism Education Futures Initiative) Core Values into the Undergraduate Curriculum. Journal of Teaching in Travel \& Tourism, 11(1), 38-75.

Bass, B. (2008). The Bass Handbook of Leadership: Theory, Research and Managerial Applications. New York: Free Press.

Bass, B., \& Riggio, R. (2005). Transformational Leadership (2nd ed.). Mahwah: Lawrence Erlbaum Associates.

Becher, T., \& Trowler, P. R. (2001). Academic Tribes and Territories: Intellectual Enquiry and the Culture of Disciplines. Buckingham \& Philadelphia: The Society for Research into Higher Education \& Open University Press. 
Bexley, E., James, R., \& Arkoudis, S. (2011). The Australian Academic Profession in Transition. Melbourne: Centre for the Study of Higher Education, University of Melbourne.

Bok, D. (2003). Universities in the Marketplace: The commercialisation of higher education. Princeton: Princeton University Press.

Boyer, E.L. (1990). Scholarship reconsidered: Priorities of the professoriate. San Francisco: Jossey-Bass.

Buchen, I. H. (2005). Finding Time for the Future and Overcoming Future Avoidance. Foresight, 7(6), 3-7.

Calvert, M., Lewis, T., \& Spindler, J. (2011). Negotiating professional identities in higher education: dilemmas and priorities of academic staff. Research in Education, 86, 25VI.

Coaldrake, P., \& Stedman, L. (1999). Academic Work in the Twenty-First Century: Changing Roles and Policies. Canberra: Department of Education, Training and Youth Affairs, Higher Education Division.

Coates, H., Dobson, I. R., Goedegebuure, L., \& Meek, L. (2010). Across the great divide: what do Australian academics think of university leadership? Advice from the CAP survey. Journal of Higher Education Policy \& Management, 32(4), 379-387.

Coles, T. (2009). Tourism Studies and the Governance of Higher Education in the United Kingdom. Tourism Geographies, 11(1), 23-42.

Coles, T., Hall, C. M., \& Duval, D. T. (2006). Tourism and post-disciplinary enquiry. Current Issues in Tourism, 9(4/5), 293-319.

Crockett, L. (2002). Agency in the life course: Concepts and Processes. In R. Dienstbier \& L. Crockett (Eds.), Agency, motivation, and the life course: Volume 48 of the Nebraska Symposium on Motivation, (pp. 1-31). Lincoln: University of Nebraska Press. 
Dale, R. (2000). Globalization and education: demonstrating a common world educational culture or locating a globally structured educational agenda? Educational Theory, $50(4), 427-448$.

Davis, G. (2005). Regulating universities: an assumption and three propositions. Paper presented at the Sustaining Prosperity, Melbourne.

Dredge, D., Benckendorff, P., Day, M., Gross, M. J., Walo, M., Weeks, P., \& Whitelaw, P. (2012). The philosophic practitioner and the curriculum space. Annals of Tourism Research, 39(4), 2154-2176.

Dredge, D., \& Hales, R. (2012). Embedded Community Case Study. In L. Dwyer, A. Gill \& N. Seetaram (Eds.), Handbook of Research Methods in Tourism: Quantitative and Qualitative Approaches (pp. 417-433). Cheltenham \& Northampton: Edward Elgar.

Drew, G. (2010). Issues and challenges in higher education leadership: Engaging for change. Australian Educational Researcher, 37(3), 57-76.

Eisenhardt, K. (1989). Agency theory: An assessment and review. The Academy of Management Review, 14(1), 57-74.

Gamage, D. T., \& Mininberg, E. (2003). The Australian and American higher education: Key issues of the first decade of the 21st Century. Higher Education, 45(2), 183-202.

Gappa, J. M., Austin, A. E., \& Trice, A. G. (2007). Rethinking Faculty Work: Higher Education's Strategic Imperative. San Francisco: John Wiley and Sons.

Gibbons, M., Limoges, C., Nowotny, H., Schwartzman, S., Scott, P., \& Trow, M. (1994). The New Production of Knowledge: The Dynamics of Science and Research in Contemporary Societies. London: SAGE.

Giddens, A. (1979). Central Problems in Social Theory: Action, Structure and Contraditcion in Social Analysis. Berkley: University of California Press. 
Giddens, A. (1984). The Constitution of Society: Outline of a theory of structuration. Cambridge: Policty Press.

Gill, A. (2012). Travelling down the road to postdisciplinarity? Reflections of a tourism geographer, Canadian Geographer, 56(1), 3-17

Gretzel, U., Isacsson, A., Matarrita, D., \& Wainio, E. (2011). Teaching Based on TEFI Values: A Case Study. Journal of Teaching in Travel \& Tourism, 11(1), 94-106.

Grint, K. (2005). Problems, problems, probems: The social construction of leadership. Human Relations, 58(11), 1467-1494.

Harland, A., \& Pickering, N. (2011). Values in Higher Education. Abingdon: Routledge.

Harland, T., Tidswell, T., Everett, D., Hale, L. \& Pickering, N. (2010). Neoliberalism and the academic as critic and conscience of society, Teaching in Higher Education, 15(1), $85-96$

Haslam, S. A., Reicher, S., \& Platow, M. (2011). The New Psychology of Leadership: Identity, Influence and Power. New York: Psychology Press.

Hazelkorn, E. (2011). Ranking and the reshaping of higher education: The battle for world wide excellence. Dublin: Centre for Social and Educational Research, Dublin Institute of Technology.

Henkel, M. (2000). Academic Identities and Policy Change in Higher Education. London and Philadelphia: Jessica Kingsley Publishers.

Henkel, M. (2005). Academic identity and autonomy in a changing policy environment. Higher Education, 49(1/2), 155-176.

Higgins-Desbiolles, F. (2010). In the eye of the beholder? Tourism and the activist academic. In P. M. Burns, C. A. Palmer \& J. M. Lester (Eds.), Tourism and visual culture Volume 1: Theories and concepts (pp. 98-106). Wallingford: CABI. 
Higgins-Desbiolles, F., \& Whyte, K. P. (2013). No high hopes for hopeful tourism: A critical comment. Annals of Tourism Research, 40, 428-433.

Holden, A. (2005). Tourism Studies and the Social Sciences. Abingdon \& New York: Routledge.

Hollinshead, K. (2009). The "Worldmaking" Prodigy of Tourism: The Reach and Power of Tourism in the Dynamics of Change and Transformation. Tourism Analysis, 14(1), $139-152$.

Hollinshead, K., Ateljevic, I., \& Ali, N. (2009). Worldmaking Agency - Worldmaking Authority: The Sovereign Constitutive Role of Tourism. Tourism Geographies, 11(4), 427-443.

Huisman, J., Weert, E. D., \& Bartelse, J. (2002). Academic careers from a European perspective: The declining desirability of the faculty position. The Journal of Higher Education, 73(1), 141-160.

Hugo, G., \& Morriss, A. (2010). Investigating the ageing academic workforce: stocktake. The National Centre for Social Applications of Geographic Information Systems, The University of Adelaide, and Anama Morriss Consulting \& Associates.

Inman, M. (2011). The Journey to Leadership for Academics in Higher Education. Educational Management Administration \& Leadership, 39(2), 228-241.

Jackson, B., \& Parry, K. (2008). A Very Short, Interesting and Reasonably Cheap Book about Leadership. London: Sage.

Jafari, J. (1991). Tourism Social Science. Annals of Tourism Research, 8(1), 13-33.

Jafari, J. (2001). The Scientification of Tourism. In V. Smith \& M. Brent (Eds.), Hosts and Guests Revisited: Tourism Issues of the 21st Century (pp. 28-41). Elmsford, New York: Cognizant Communications.

Jafari, J. (2003). Research and Scholarship. The Journal of Tourism Studies, 14(1), 6-16. 
Jensen, M., \& Meckling, W. (1976). Theory of the Firm: Managerial behavior, agency costs and ownership structure. Journal of Financial Economis, 3(4), 305-360.

Jones, S., Applebee, A., Harvey, M., \& Lefoe, G. (2010). Scoping a distributed leadership matrix for higher education. Paper presented at the 33rd Higher Education Research and Development Society of Australasia, Melbourne.

Kezar, A. (2000). Pluralistic Leadership: Incorporating Diverse Voices. The Journal of Higher Education, 71(6), 722-743.

Kezar, R., \& Carducci, M. (2006). Rethinking the "L" Word in Higher Education: The revolution of research in leadership. San Fransisco: ASHE Higher Education Report/Jossey-Bass.

Kogan, M., \& Teichler, U. (2007). Key Challenges to the Academic Profession. Paris and Kassel: UNESCO Forum on High Education Research and Knowledge.

Koopman-Boyden, P.G., \& Macdonald, L. (2003). Ageing, Work Performance and Managing Ageing Academics. Journal of Higher Education Policy and Management, 25(1), 2940.

Liburd, J. (2012). Tourism Research 2.0. Annals of Tourism Research, 39(2), 883-907. Latour, B. (1987). Science in Action: How to Follow Scientists and Engineers through Society. Milton Keynes: Open University Press.

Lew, A. (2007). Invited Commentary: Tourism Planning and Traditional Urban Planning Theory: Planners as Agents of Social Change. Leisure/Loisir: Journal of the Canadian Association of Leisure Studies in Higher Education, 31(2), 383-392.

Lyons, K. (2010). Room to Move? The challenges of career mobility for tourism education. Journal of Hospitality \& Tourism Education, 22(2), 51-55.

Macfarlane, B. (2011). Professors as intellectual leaders: formation, identity and role. Studies in Higher Education, 36(1), 57-73. 
Magner, D. (1999). The graying professoriate. The Chronicle of Higher Education, 3 September, A18-A21.

Marginson, S. (1999). The Enterprise University Comes to Australia. Paper presented at the Australian Association for Research in Education, Melbourne.

Marginson, S. (2008). Academic creativity under new public management foundations for an investigation. Educational Theory, 58(3), 269-286.

Marginson, S., \& Considine, M. (2000). The Enterprise University: Power Governance and Reinvention in Australia. Cambridge: Cambridge University Press.

Marginson, S., \& Rhoades, G. (2002). Beyond national states, markets, and systems of higher education" A glonacal agency heuristic. Higher Education, 43, 281-309.

Marginson, S., \& Sawir, E. (2005). Interrogating global flows in higher education. Globalisation, Societies and Education, 3(3), 281-309.

Marshall, S. J., Orrell, J., Cameron, A., Bosanquet, A., \& Thomas, S. (2011). Leading and managing learning and teaching in higher education. Higher Education Research \& Development, 30(2), 87-103.

Maslow, A. (1987). Motivation and Personality (3rd ed.). New York: Harper \& Row.

McCarty, L. P. (2011). Cosmopolitan Education. Colleagues, 6(1), article 5.

McInnis, C. (2000). Changing Academic Work Roles: the everyday realities challenging quality in teaching. Quality in Higher Education, 6(2), 143.

Messick, D., \& Kramer, R. (2005). The Psychology of Leadership: New Perspectives and Research. Mahwah: Lawrence Erlbaum Associates.

Moscardo, G., \& Murphy, L. (2011). Toward Values Education in Tourism: The Challenge of Measuring the Values. Journal of Teaching in Travel \& Tourism, 11(1), 76-93.

Morgan, N. (2012). Time for 'mindful' destination management and marketing. Journal of Destination Marketing \& Management, 1, 8-9. 
Nash, D. (2007). The Study of Tourism: Anthropological and sociological beginnings. Oxford: Elsevier.

Northouse, P. G. (2009). Leadership: Theory and Practice. London: Sage.

Nussbaum, M. (1997). Cultivating Humanity: A Classical Defense of Reform in Liberal Education. Cambridge: Harvard University Press.

Nussbaum, M. (2010). Not for Profit: Why Democracy needs the Humanities. Woodstock: Princeton University Press.

Pearce, P. (2005a). Australian Tourism Education: The Quest for Status. In C. H. Hsu (Ed.), Global Tourism Higher Education: Past Present and Future (pp.251-267). Binghamton: Haworth Information Press.

Pearce, P. (2005b). Professing Tourism: Tourism academics as educators, researchers and change leaders. Journal of Tourism Studies, 16(2), 21-33.

Pearce, P. (2011). The Study of Tourism: Foundations from Psychology. Oxford \& Amsterdam: Emerald

Phillips, R. (2005). Challenging the primacy of lectures: The dissonance between theory and practice in university lecturing. Journal of University Teaching and Learning Practice, 2(1).

Pritchard, A., Morgan, N., \& Ateljevic, I. (2011). Hopeful tourism: A New Transformative Perspective. Annals of Tourism Research, 38(3), 941-963.

Pusser, B., Kempner, K., Marginson, S., \& Ordorika, I. (2012). Universities and the Public Sphere: Knowledge Creation and State Building in an Era of Globalization. London and New York: Routledge.

Rafferty, A., \& Griffith, M. (2004). Dimensions of transformational leadership: Conceptual and empirical extensions. The Leadership Quarterly, 15, 329-354. 
Ramsden, P. (2003). Learning to Teach in Higher Education (2nd edition). Abingdon, Oxon, UK: Routledge Falmer.

Ren, C., Pritchard, A., \& Morgan, N. (2010). Constructing tourism research: A Critical Inquiry. Annals of Tourism Research, 37(4), 885-904.

Richards, D. (2012). Leadership for Learning in Higher Education: The Student Perspective. Educational Management Administration \& Leadership, 40(1), 84-108.

Ross, S. (1973). The economic theory of agency: The principal's problem. American Economic Review, 63(1), 7-63.

Schuster, J. H., \& Finkelstein, M. J. (2006). The American Faculty: The Restructuring of Academic Work and Careers. Baltimore: Johns Hopkins University Press.

Seeber, M. (2011). Efficacy and limitations of research steering in different disciplines. Studies in Higher Education, 1-19.

Sen, A. (1985). Well-being, agency and freedom: The Dewey Lectures 1984. The Journal of Philosophy, 82(4), pp 169-221.

Sen, A. (1999). Develeopment as Freedom. Oxford: Oxford University Press.

Sharrock, G. (2012). Four management agendas for Australian universities. Journal of Higher Education Policy and Management, 34(3), 323-337.

Sheldon, P. J., Fesenmaier, D. R., \& Tribe, J. (2011). The Tourism Education Futures Initiative (TEFI): Activating Change in Tourism Education. Journal of Teaching in Travel \& Tourism, 11(1), 2-23.

Smith, S. L. J. (2010). The Discovery of Tourism. Oxford \& Amsterdam: Emerald.

Smith, S., Ward, V., \& House, A. (2011). 'Impact' in the proposals for the UK's Research Excellence Framework: Shifting the boundaries of academic autonomy. Research Policy, 40(10), 1369-1379. 
Teichler, U. (2003). The Future of Higher Education and the Future of Higher Education Research. Tertiary Education and Management, 9(3), 171-185.

Tribe, J. (1997). The Indiscipline of Tourism. Annals of Tourism Reserach, 24(3), 638-657.

Tribe, J. (2002). The Philosophic Practitioner. Annals of Tourism Research, 29(2), 228-257.

Tribe, J. (2006). The Truth about Tourism. Annals of Tourism Research, 33(2), 360-381.

Tribe, J. (2010). Tribes, territories and networks in the tourism academy. Annals of Tourism Research, 37(1), 7-33.

Trowler, P. (2010). UK Higher Education: Captured by New Managerialist Ideology? In V.

L. Meek, L. Goedegebuure, R. Santiago \& T. Carvalho (Eds.), The Changing

Dynamics of Higher Education Middle Management. (Vol. 33, pp. 197-211).

Dordrecht: Springer Netherlands.

Tynan, B., \& Mark, J. W. L. (2009). Tales of adventure and change: academic staff members' future visions of higher education and their professional development needs. On the Horizon, 17(2), 98-108.

Van Der Wende, M. (2007). Internationalization of higher education in the OECD countries: challenges and opportunities for the coming decade. Journal of Studies in International Education, 11(3/4), 274-289.

Walumbwa, F. O., Avolio, B. J., Gardner, W. L., Wernsing, T. S., \& Peterson, S. J. (2008). Authentic Leadership: Development and Validation of a Theory-Based Measure. Journal of Management, 34, 89-126.

Whitchurch, C. (2012). Expanding the parameters of academia. Higher Education, 64(1), 99117.

World Development Bank. (1999). World Development Bank: Knowledge for Development. Washington: World Development Bank. 
Table 1 - TEFI Values

\begin{tabular}{|l|l|}
\hline VALUE & EXPLANATION \\
\hline Ethics & $\begin{array}{l}\text { Involves striving for actions that are deemed "good" based } \\
\text { on principles and values of honesty }\end{array}$ \\
\hline Stewardship & $\begin{array}{l}\text { Involves the pursuit of sustainability, responsibility and service to the } \\
\text { community }\end{array}$ \\
\hline Knowledge & $\begin{array}{l}\text { Includes the expertise and skills acquired by education and experience, } \\
\text { and what is known in a particular field including facts, information, } \\
\text { theories and models }\end{array}$ \\
\hline Professionalism & $\begin{array}{l}\text { Refers to conduct that is aligned with ethical and professional behavior, } \\
\text { and incorporates principles such as leadership. Practicality, concern for } \\
\text { relevance and timeliness }\end{array}$ \\
\hline Mutuality & $\begin{array}{l}\text { Incorporates respect for diversity, inclusion, equity, humility and } \\
\text { collaboration, wherein the long-term benefits being a respect, self - } \\
\text { awareness and appreciation of diverse opinions, cultures and practices. }\end{array}$ \\
\hline
\end{tabular}

Source: Barber, 2011; Sheldon et al, 2011. 
Figure 1 - Factors contributing to tourism faculty leadership opportunities

Systemic influences

Neoliberalism, globalisation, reform
Individual influences

Individual behaviors \& characteristics
The organisation

(Mission, objectives, values, plans)

Effective freedom to act shaped by organizational opportunities
The academy

(Disciplinary \& tribal values \& interests)

Social freedom to act shaped by disciplinary structures, academic tribes \& departmentalism
The Individual

(Individual motivations, behaviors)

\section{Individual's Work Profile}

Scholarship of Application

Scholarship of Teaching

\section{Leadership Opportunities \& Actions}

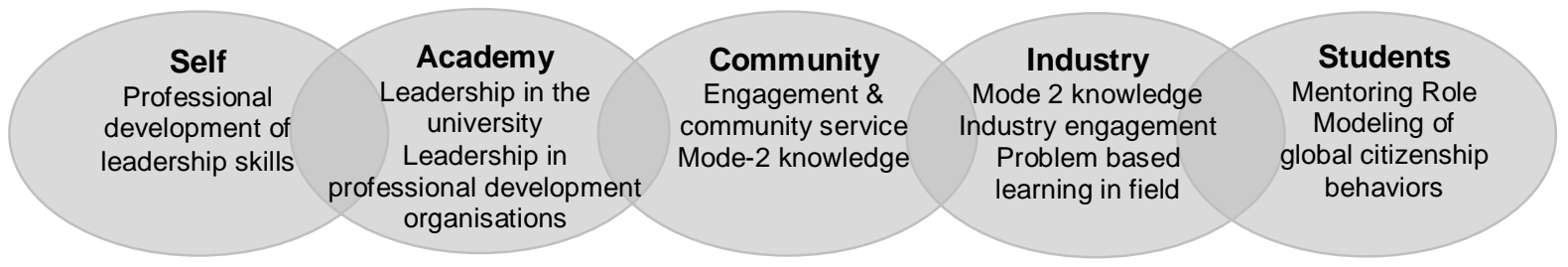


Table 2 - Boyer's (1990) Scholarship Dimensions and Opportunities and Strategies for

\section{Academic Leadership in Tourism}

\begin{tabular}{|c|c|c|}
\hline $\begin{array}{c}\text { Boyer } \\
\text { Scholarship } \\
\text { Dimensions }\end{array}$ & Explanation & $\begin{array}{c}\text { Opportunities and strategies for Academic Leadership in } \\
\text { Tourism (an exploratory list) }\end{array}$ \\
\hline Discovery & $\begin{array}{l}\text { Advancement of } \\
\text { Knowledge }\end{array}$ & $\begin{array}{l}\text { - Challenging what 'types of knowledge' are deemed } \\
\text { worth advancing by institutions and funding bodies } \\
\text { - Furthering insightful new approaches to knowledge } \\
\text { generation and analysis of information } \\
\text { - Co-produce new knowledge using 'Mode 2' knowledge } \\
\text { production } \\
\text { - Publish in peer-reviewed academic forums, industry } \\
\text { journals and other media }\end{array}$ \\
\hline Integration & $\begin{array}{l}\text { Positioning and } \\
\text { interpreting } \\
\text { knowledge in broader } \\
\text { contexts and across } \\
\text { disciplines }\end{array}$ & $\begin{array}{l}\text { - Multi/transdisciplinary literature reviews, research book } \\
\text { or textbook for a broad audience } \\
\text { - Collaborate outside the discipline/field of study in a } \\
\text { multi-disciplinary project } \\
\text { - Engage in public intellectualism by positioning and } \\
\text { making sense of knowledge for the benefit of a non- } \\
\text { specialist audience } \\
\text { - Communicate and disseminate knowledge in places and } \\
\text { spaces where it can assist in understanding or solving } \\
\text { complex real world problems }\end{array}$ \\
\hline Application & $\begin{array}{l}\text { Aid society, industry, } \\
\text { professions, } \\
\text { government in } \\
\text { addressing problems }\end{array}$ & $\begin{array}{l}\text { - Industry or government consultancies } \\
\text { - } \quad \text { Academic activism } \\
\text { - } \quad \text { Leadership roles in professional organisations } \\
\text { - Incorporing students' professional growth } \\
\text { scenarios that require leaners to apply theory, confront } \\
\text { complexities and collaborate with external stakeholders } \\
\text { - Media engagement and contributing to political } \\
\text { - } \text { discourses about an issue } \\
\text { volunteering opportunities for learners to aid society by } \\
\text { applying and enhancing their knowledge and skills }\end{array}$ \\
\hline Teaching & $\begin{array}{l}\text { Design, evaluate and } \\
\text { reflexively engage in } \\
\text { teaching curriculum } \\
\text { and practices }\end{array}$ & $\begin{array}{l}\text { - Engaging in critical, reflexive teaching practice } \\
\text { - } \quad \text { Seveloping and testing teaching materials } \\
\text { creative thinking in learners } \\
\text { - Informing teaching through (multi- and/or trans- } \\
\text { disciplinary) research } \\
\text { - Engaging in research on effective teaching and learning } \\
\text { - Mentoring graduate students in their teaching activities } \\
\text { - Designing staged assessment for a program }\end{array}$ \\
\hline
\end{tabular}




\begin{tabular}{|l|l|l|}
\hline & $\begin{array}{l}\text { Service/instructional teaching in the profession } \\
\bullet\end{array}$ & $\begin{array}{l}\text { Engaging and learning from stakeholders, including } \\
\text { students, in curriculum and assessment design }\end{array}$ \\
\hline
\end{tabular}

